\title{
Long-term phosphorus accumulation and removal efficiency in a land-based wastewater treatment system in the UK
}

\author{
Maria del Mar Batista Seguí a, Sean Tyrrel FCIWEM, CEnv ${ }^{a}$, Tim Hess ${ }^{\text {a }}$, Ruben \\ Sakrabani ${ }^{a}$ and David Knaggs ${ }^{b}$
}

a School of Water, Energy and Environment (SWEE), Cranfield University, MK43 0AL, UK

${ }^{\mathrm{b}}$ Albion Water Limited, Customer Services, Harpenden Hall, Southdown Road, Harpenden, Herts, AL5 1TE, UK.

\begin{abstract}
The study aims to assess the long-term phosphorus (P) removal in a land treatment system (LTS)in the UK. Different sections of the site have been irrigated with wastewater effluent for different periods of time for up to 85 years. The amounts of $\mathrm{P}$ discharged and accumulated were calculated from historical data, estimations of water consumption, composition, and soil measurement. The total P input during the study period was estimated to be $90010 \mathrm{~kg}$, the average $\mathrm{P}$ removal was $4 \%$ and there was no significant difference in the total $\mathrm{P}$ accumulated between plots irrigated for different periods, indicating that the sorption capacity of the soil might be saturated. Despite the low P retention rates in the LTS, there is no evidence that emissions from this system are affecting $\mathrm{P}$ concentrations in either the nearby river or the local chalk aquifer. Gaps remain, however, in performance optimization and longevity forecasting.
\end{abstract}

Keywords: retention, percolation, soil, wastewater tertiary treatment

*Address correspondence to Sean Tyrrel, School of Water, Energy and Environment of Cranfield University, Cranfield, MK43 0AL, UK.E-mail: s.tyrrel@cranfield.ac.uk Tel:+44 (0)1234 750111 


\section{Introduction}

Land Treatment Systems (LTS) are "terrestrial systems where pre-treated wastewater is applied onto the land surface to achieve a specified level of treatment through natural physical, chemical, and biological processes within the plant-soil-water matrix" (Crites et al. 2006). Treatment occurs as the applied wastewater interacts with the soil and the vegetation, and the biofilm grown in the process. Many of the treatment processes are similar to those occurring in trickling filters and other attached growth systems. Soil P retention mechanisms are physical, chemical, biological processes and/or plant uptake (Crites et al. 2000). Physical retention can retain $\mathrm{P}$ by deposition and infiltration, where vegetation and dense root systems help to decrease water velocity and increase contact time of $\mathrm{P}$ with the soil surface, this mechanism has greater influence in particulate P than dissolved P (Roberts et al. 2012). These processes can remove biodegradable organics, pathogens, metals, nitrogen and phosphorus (Tzanakakis et al. 2007). LTS can offer a sustainable alternative tertiary treatment to small treatment works with available land, where low tech, low carbon, and low maintenance solutions are required (Tyrrell 2016). They can also be an option for small-scale applications such as sustainable urban drainage systems where vegetated units are used to encourage infiltration, detention and moderate storm water run-off while improving water quality (Charlesworth et al. 2016) or provide a treatment option for industrial wastewaters in places where there is a lack of specialized operators and land is relatively affordable (Taebi and Droste 2008). However, these systems normally present limitations that can influence the treatment performance, such as higher land requirements than other more intensive treatments $\left(0.24 \mathrm{~m}^{2}\right.$ per $\mathrm{m}^{3}$ flow area requirement for activated sludge process and $40 \mathrm{~m}^{2}$ per $\mathrm{m}^{3}$ flow for free water surface wetlands (Austin and Nivala 2009)), or constraints based on the site conditions (e.g. soil texture or soil chemistry).

When wastewater is not treated to an appropriate level, it can lead into the release of soluble phosphorus to water bodies causing eutrophication, and consequent impacts on the quality of the aquatic ecosystem by oxygen depletion (Smith 2003). The main phosphorus removal mechanisms in natural treatments are: vegetation and microbial uptake, and soil chemical precipitation and adsorption (Reddy et al. 1999). While vegetation and microbial uptake are biological processes that can be restored through appropriate design and maintenance; chemical processes such as precipitation and adsorption, depend on soil properties that are reduced over 
time and eventually exhausted when the equilibrium in the pore water is reached or the functional groups on the soil surface are saturated.

Although these systems have been in use for a long time and in a wide range of soils and climate conditions, most monitoring studies have been conducted on young treatment systems and for short periods of time. Therefore, there is limited information regarding removal performance in the long-term and lifespan estimations. Batista et al. (2017) reviewed field and laboratory experiences, and methodologies to estimate P removal in the long-term in LTS. They found that laboratory experiments can be used to compare materials but not for lifespan predictions because the standard methodology (short contact time or liquid-solid solutions ratio) does not represent the systems and interactions with the ecosystem. In addition, results from P removal field experiments presented highly variable removal rates (8-99\%) in different aged unsaturated soil infiltration systems (14-27 years), and different soil types and climates, making the comparison between studies difficult.

In the UK, during the period 1920-1970, LTS were used as a tertiary treatment to provide confidence with respect to meeting the so-called Royal Commission 20:30 biological oxygen demand: suspended solids discharge consent standard which was widely applied at British wastewater treatment works (Gray 1989). Many of these LTS were subsequently inherited by the regional water authorities following the Water Act (1973) and remain in use today (Tyrrell 2016). Sweaney (2011) aimed to identify sustainable wastewater technologies used by the water industry and provided evidence of the wastewater quality achieved by British water companies using LTS technologies. The study identified 20 LTS, mostly in the form of grass plots, and obtained performance data from 13 systems belonging to two water companies in relation to organic matter, suspended solids and ammonia removal, but there is a lack of knowledge about long-term $P$ removal behaviour or age of the systems.

The aim of this study is to assess P accumulation over time in a LTS in order to evaluate for how long this type of system can make a useful contribution to wastewater treatment. Additional objectives are to estimate the soil $\mathrm{P}$ removal efficiency and the $\mathrm{P}$ accumulated over time, and to evaluate the impact of the degree of saturation of soil phosphorus on the quality of the water entering surface and groundwater bodies. The chosen case study is a LTS in the south of England (UK), where different parts of the field have been irrigated with secondary wastewater effluent for different periods of time (up to 85 years). 


\section{Materials and Methods}

\section{Study site description}

The site is a riparian meadow of approximately $20000 \mathrm{~m}^{2}$ surface area, bordering the River

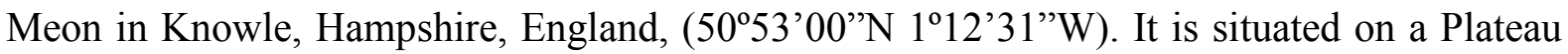
Gravel and alluvium parent material with clay loam soil texture (Tyrrell 2016). The field has been irrigated with secondary wastewater effluent from Knowle Sewage Treatment Works (STW) for approximately 85 years. The current vegetation is presently grassland with perennial herbaceous plants such as stinging nettles (Urtica dioica) in the irrigated parts. The vegetation is not harvested or removed from the site.However, the historical vegetation management of the site uncertain.

Knowle STW (Error! Reference source not found.) is thought to have been installed in the early 1930's to serve the Knowle psychiatric hospital which, between 1852 and 1996 had an average population of 2000 (patients and staff) and large laundries and workshops (Burt 2003). From 2000 onwards the hospital site was redeveloped into a residential area with 700 domestic properties, a high security hospital and commercial businesses. The STW utilises primary and secondary treatment processes prior to discharge to the riparian meadow (the "discharge field") for tertiary treatment.

The secondary wastewater effluent is discharged via a chamber distributing flows through a sluice system onto the discharge field (irrigation). Prior to the 1990's, the effluent delivery system consisted of a channel and floodgate system that irrigated a larger area of the discharge field. Historical maps (Landmark Information Group 1932) show that the original discharge channel that covered half of the field was elongated to irrigate the whole field around 1950. This system was replaced in the 1990's with a pipeline along approximately half of the discharge field with outlets of $150 \mathrm{~mm}$ diameter and $15 \mathrm{~m}$ spacing between outlets. The wastewater discharge is controlled by the plant operator who opens the outlets, based on observation and experience. Only two to three outlets are opened simultaneously to allow the recovery of aerobic conditions in the soil and to avoid flooding. All secondary wastewater effluent discharged on to the site infiltrates in to the soil and no surface runoff has been observed from the discharge field to the river. The system has no flow meters, hence the amount of water discharged to the field is uncertain. However, the inputs have been estimated from water consumption in Knowle hospital and village over the study period. 
For this study, the discharge field was divided into three sections (Error! Reference source not found.). Section A has been irrigated with secondary wastewater effluent from the STW since the early 1930s and is still in operation; section B was irrigated until the end of the 1990s, when the sluice system was replaced by the pipe; and Section $\mathrm{C}$, which, based on historical maps, was irrigated from approximately 1950 until 1990 (Landmark Information Group 1932).

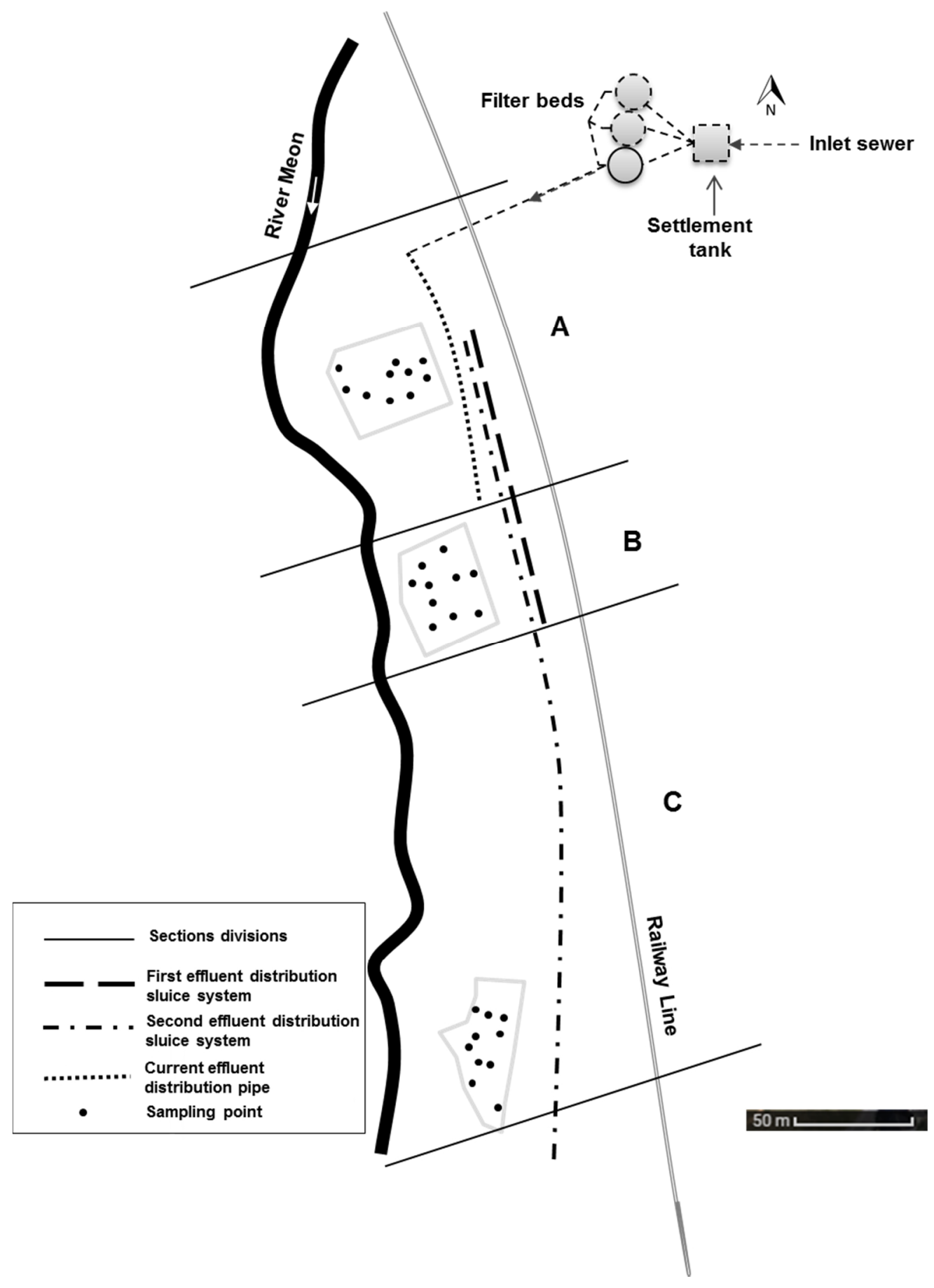

Figure 1 Diagram of the land treatment system in Knowle (UK) showing the sewage treatment works location, the historical discharge systems, the division of the sampling sections and sample locations. 


\section{Soil analysis}

Stratified random sampling was used to sample the soil in each of the three sections. Due to unclear boundaries between the sections, and to avoid sampling in, or close to, the boundaries, equal-sized plots of $2000 \mathrm{~m}^{2}$ were defined in each section. In each plot, 10 points were randomly selected with $10 \mathrm{~m}$ minimum distance between them. It was judged that the sampling density (equivalent to 50 samples/ha) would provide sufficient information about the total phosphorus (TP) variability, since sampling protocols for $\mathrm{P}$ in crop production recommend 48 samples/ha as a trade-off between practicality and accuracy (Force et al. 2006). At each point, a composite sample of the 0-40 cm layer was taken with a Dutch auger, based on the method of Falkiner and Polglase (1999). The samples were pre-treated using BS ISO 11464:2006 Soil quality. Pre-treatment of samples for physio-chemical analysis, (BSI Standards Limited. 2006) and TP was determined with aqua regia digestion using BS 7755-3.13:1998, ISO 11047:1998 Soil quality. Chemical methods. Determination of cadmium, chromium, cobalt, copper, lead, manganese, nickel and zinc in aqua regia extracts of soil (BSI Standards Limited. 1998), and phosphorus measured colorimetrically. The mean TP concentration $\left(\mathrm{C}_{\mathrm{p}}\right)$ from triplicates laboratory samples of $\mathrm{n}=10$ samples in each section $(\mathrm{kg} \mathrm{P} / \mathrm{kg})$ by acid digestion was used for mass balance calculations. This method includes the sum of organic and inorganic forms of phosphorus in unfiltered water samples. Samples are hydrolysed with acid and digested (heated) which breaks down strong chemical bonds and allows all phosphorus in the sample to be measured colorimetrically, and therefore, the majority of the phosphorus sorbed from the wastewater application. Bulk density was estimated to be to $940 \mathrm{~kg} / \mathrm{m}^{3}$ from top soil properties (Centre for Ecology \& Hydrology 2007) for top soil bulk density representative of $0-15 \mathrm{~cm}$ soil depth. Two different sources were used as a reference sample of unirrigated soil: the top soil background levels for TP of 560 samples in a $50 \mathrm{~km}$ radius of clay loam soils type and grassland land use from the National Soil Inventory (NSI) (National Soil Resources Institute 2014), referred to in the text as 'regional average'; and Tyrrell's (2016) results from an adjacent clay loam, grass field situated in Knowle STW, referred to as 'adjacent site'. A one-sample ttest showed that the TP of the adjacent site was not significantly different from the regional average $(\mathrm{t}=0.298 ; \mathrm{p}=0.766)$.

\section{Water balance of the site over the study period}

The water inputs to the systems considered are precipitation and irrigation. Long-term average monthly rainfall was estimated from the $\mathrm{CEH}$ - Gridded Estimates of Areal Rainfall (CEH - 
GEAR) which contains $1 \mathrm{~km}$ gridded estimates of monthly rainfall for UK from 1890 to 2015 (Keller et al. 2015). It is assumed that the volume of water consumed in the hospital and the village equals the secondary wastewater effluent. Therefore, irrigation was calculated from the estimated water consumption in Knowle hospital and village over the study period. Average domestic water consumption was estimated to be 1261 /capita in 1930 and currently 150 1/capita (Anglian Water Ltd. 2008). The water consumptions between these dates was interpolated linearly.

The water outputs of the system are evapotranspiration and percolation. Runoff was assumed to be zero since it has not been observed in the study field. The reference evapotranspiration was calculated using the Penman-Monteith equation (Land and Water Division of FAO 2012). Air humidity, wind speed and radiation were estimated with the ETo calculator by the missing data estimation procedures described in Allen et al. (1998). Monthly maximum and minimum temperature were obtained for 1903 to 1999 period from Southampton (Mettofice 2016) (50 $53^{\prime} 59^{\prime \prime} \mathrm{N} 01^{\circ} 23^{\prime} 44^{\prime \prime} \mathrm{W}$ ) to calculate long-term average monthly evapotranspiration (ETc), in this case ETc is equal to reference evapotranspiration since the crop at the site is well watered grass.

\section{Phosphorus inputs to the site over the study period}

The total mass of $\mathrm{P}$ discharged to the discharge field $\left(\mathrm{P}_{\mathrm{d}}\right)$ was estimated using Eq. (1) from the site history accounting for population and different $\mathrm{P}$ content in domestic wastewater for every year through the entire study period (1932-2016). Although P levels in the faeces changes with diet over time and space, in this study, they are assumed to be constant since the impact of changes in diet on $\mathrm{P}$ content effluent of on-site wastewater treatment has not been quantified yet (O'Keeffe et al. 2015). A 25\% P removal was applied to account for the effect of primary sedimentation, the $\mathrm{P}$ biologically removed in the bio filters and consequently the $\mathrm{P}$ exported from the works in the sludge. This $\mathrm{P}$ removal rate in primary and secondary treatments was calculated from wastewater inflow and outflow data from Knowle sewage treatment plant from December 2014 to March 2016.

Therefore, total $\mathrm{P}$ added to the discharge field was calculated from:

$$
P_{d}=\sum_{i=y_{0}}^{y_{f}} 365 \cdot \mathrm{C}_{i} \cdot \mathrm{P}_{i} \cdot 0.75
$$

where 
$P_{d}$ is the $\mathrm{P}$ added to the discharge field with the secondary wastewater effluent $(\mathrm{kg})$

$P_{i}$ is the population in year i (capita)

$C_{i}$ is the daily amount of $\mathrm{P}$ discharged to the field in the year $\mathrm{i}(\mathrm{kg} / \mathrm{capita} /$ day $)$

$y_{0}=1932$

$y_{f}=2016$

The population each year was estimated from admission registers of the hospital from Burt (2003). In between, the population data was interpolated linearly until the hospital closed in 1996. From 2000 to 2016, when the area was redeveloped for residential use, population was calculated considering 2.4 persons/household occupancy (Office of National Statistics 2013) for 700 houses. $\mathrm{C}_{\mathrm{i}}$, was estimated from a study of human waste contributions to $\mathrm{P}$ loads to domestic wastewater in UK (Gilmour et al. 2008) and allowing for the UK P detergent consumption from 1950 to 1998 (Foundation for Water Research, 2006).

The estimated load $\left(\mathrm{P}_{1}\right)\left(\mathrm{kg} / \mathrm{m}^{2}\right)$ discharged to each section was calculated in relation to the pipe length that irrigates each of the sections.

\section{Phosphorus removal}

The average long-term $\mathrm{P}$ removal $\left(\mathrm{P}_{\mathrm{r}}\right)(\%)$ was determined by Eq. (2) :

$$
P_{r}=\frac{(C p-R)}{P_{l}} 100
$$

where

$C p$ is the mean TP concentration from triplicates of $\mathrm{n}=10$ samples in each section $\left(\mathrm{kg} / \mathrm{m}^{2}\right)$

$R$ is site reference for TP soil concentration $\left(\mathrm{kg} / \mathrm{m}^{2}\right)$.

$P_{l}$ is the estimated $\mathrm{P}$ load discharged to each section $\left(\mathrm{kg} / \mathrm{m}^{2}\right)$.

\section{Statistical analysis}

Measurements of TP in soil samples were tested for normality by using the Shapiro-Wilk U test. Significant differences were determined at $\alpha=0.05$. Comparisons of means were by one sample and paired samples t-tests and one-way analysis of variance (ANOVA). Tukey's HSD (Honestly Significant Difference) tests were applied for Post-ANOVA pair- wise comparisons to identify significant differences among means. All statistical analyses were performed using IBM SPSS Statistics 23 (IBM Corporation, Armonk, NY, USA). 


\section{Results}

\section{Water balance}

The hydrological (natural and engineered) cycle drives the balance of $\mathrm{P}$ inputs and outputs of the system while the soil system controls the P removal processes. The inputs and outputs of Knowle's land treatment system for a long-term average year (Figure 2) show that the secondary wastewater effluent discharged to the field (irrigation) has dominated in comparison with precipitation in both main irrigation periods. The average irrigation for the study period is $272 \mathrm{~m}^{3} /$ day. For the last period of operation (2000-2016) the estimated domestic water consumption for Knowle village is $250 \mathrm{~m}^{3} /$ day (Table 1), which corresponds to recent Albion Water STW influent monitoring.

Table 1 Estimated water consumption in Knowle during the study period.

\begin{tabular}{lcccc}
\hline From & to & Population & \multicolumn{2}{c}{ Water consumption } \\
& (year) & (persons) & (l/person/day) & $\left(\mathrm{m}^{3} /\right.$ day $)$ \\
\hline 1932 & 1950 & 2000 & 131.0 & 262 \\
1951 & 1955 & 2000 & 132.2 & 264 \\
1956 & 1960 & 2000 & 133.3 & 267 \\
1961 & 1970 & 2000 & 135.8 & 272 \\
1971 & 1977 & 2000 & 137.5 & 275 \\
1978 & 1981 & 2000 & 138.3 & 277 \\
1982 & 1987 & 2000 & 139.7 & 279 \\
1988 & 1990 & 2000 & 140.3 & 281 \\
1991 & 1994 & 2000 & 141.1 & 282 \\
1995 & 1996 & 2000 & 141.4 & 283 \\
2000 & 2016 & 1680 & 150.0 & 252 \\
& & & Average & 272 \\
\hline
\end{tabular}




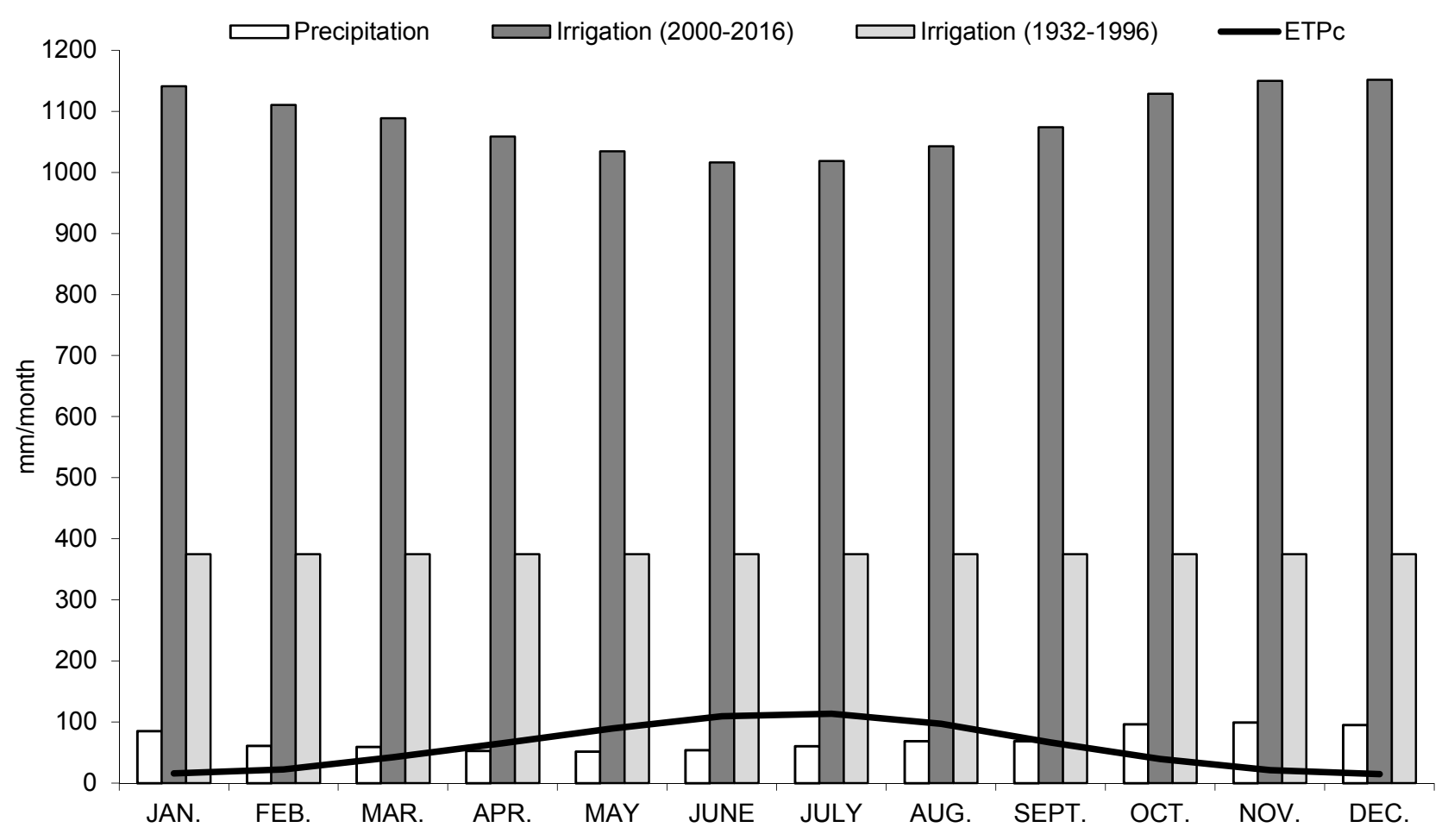

Figure 2 Monthly average (1890 to 2015) rainfall, ET $\mathbf{c}_{\mathrm{c}}$ and irrigation during the two main irrigation periods, 1932-1996 and 2000-2016 at Knowle (UK) land treatment system.

\section{Phosphorus inputs over the study period}

The total amount of $\mathrm{P}$ discharged through irrigation $\left(\mathrm{P}_{\mathrm{d}}\right)$ during the entire period (1932-2016) of operation was $\approx 90000 \mathrm{~kg}$ (equivalent to $4.5 \mathrm{t} / \mathrm{ha}$ ) (Error! Reference source not found. and Error! Reference source not found.). Estimated P loading rates in the early period, when the entire field was irrigated, was $0.04 \mathrm{~kg} / \mathrm{m}^{2} / \mathrm{a}$. For the later period when only Section A was irrigated, P load was calculated to be $0.06 \mathrm{~kg} / \mathrm{m}^{2} / \mathrm{a}$. Assuming uniform application, P loading rates are in the range of other wastewater irrigation experiences such as Eveborn et al. (2014) with loading rates ranging from $0.03-0.54 \mathrm{~kg} / \mathrm{m}^{2} / \mathrm{a}$, or Dzakpasu et al. (2015) constructed wetland loading rate of $0.016 \mathrm{~kg} / \mathrm{m}^{2} / \mathrm{a}$. 
Table 2 Estimated total phosphorus $P$ added to the discharge field with the secondary wastewater effluent during the study period.

\begin{tabular}{ccccccc}
\hline From & to & Population & $\begin{array}{c}\text { TP load to } \\
\text { sewer by } \\
\text { domestic } \\
\text { wastewater } \\
\text { in the UK }\end{array}$ & $\begin{array}{c}\text { TP influent } \\
\text { by domestic } \\
\text { wastewater } \\
\text { in Knowle } \\
\text { STW }\end{array}$ & Years & $\begin{array}{c}\text { TP after } \\
\text { primary and } \\
\text { secondary } \\
\text { treatment }\end{array}$ \\
\hline (year) & (persons) & (g/person/day) & (kg/year) & (kg) \\
\hline 1932 & 1950 & 2000 & 1.40 & 767 & 19 & 14564 \\
1951 & 1955 & 2000 & 1.42 & 777 & 5 & 3887 \\
1956 & 1960 & 2000 & 1.72 & 942 & 5 & 4709 \\
1961 & 1970 & 2000 & 2.04 & 1117 & 10 & 11169 \\
1971 & 1977 & 2000 & 2.43 & 1330 & 7 & 9313 \\
1978 & 1981 & 2000 & 3.10 & 1697 & 4 & 6789 \\
1982 & 1987 & 2000 & 3.25 & 1779 & 6 & 10676 \\
1988 & 1990 & 2000 & 3.22 & 1763 & 3 & 5289 \\
1991 & 1994 & 2000 & 2.87 & 1571 & 4 & 6285 \\
1995 & 1996 & 2000 & 2.26 & 1237 & 2 & 2475 \\
2000 & 2016 & 1680 & 1.90 & 874 & 17 & 14855 \\
& & & & Total & 82 & 90010
\end{tabular}

a(Gilmour, Blackwood, Comber, et al., 2008), (Foundation for Water Research, 2006). 
Table 3 Total estimated phosphorus (Pd) distributed during the different irrigation periods and to the sections, total phosphorus load (PI) to each section, total phosphorus concentration $(C p)$, site reference concentration $(R)$ and $P$ removal $(P r)$ for each section of the discharged field. (-) no irrigation during this period. Smax from Tyrell (2016).

\begin{tabular}{lrrrrr} 
& & Section A & Section B & Section C & Total \\
\hline \multirow{2}{*}{ Period } & $1932-1950$ & 12537 & 6757 & - & 17145 \\
\cline { 2 - 6 } & $1950-2000$ & 15537 & 8087 & 30003 & 53577 \\
\cline { 2 - 6 } & $2000-2016$ & 17145 & - & - & 19288 \\
\hline $\mathrm{P}_{\mathrm{d}}(\mathrm{kg})$ & Total & 42219 & 14788 & 30003 & 90010 \\
\hline $\mathrm{P}_{1}\left(\mathrm{~kg} / \mathrm{m}^{2}\right)$ & & 6.75 & 7.39 & 2.80 & \\
\hline $\mathrm{C}_{\mathrm{p}}\left(\mathrm{kg} / \mathrm{m}^{2}\right)$ & & 0.57 & 0.67 & 0.41 & \\
\hline $\mathrm{R}\left(\mathrm{kg} / \mathrm{m}^{2}\right)$ & 0.35 & 0.35 & 0.35 & \\
\hline $\mathrm{P}_{\mathrm{r}}(\%)$ & 3 & 4 & 3 & \\
\hline $\mathrm{Smax}(\mathrm{mg}$ & & 1240 & & \\
$\mathrm{P} / \mathrm{kg})$ & & & & & \\
\hline
\end{tabular}

\section{P removal}

The percentage of $\mathrm{P}$ removal, which includes the difference with the reference sample, varies between 3 and 4\% in the different sections (Table 3). If the P removal is calculated without considering natural $\mathrm{P}$ in the soil (for which we have no measured starting value), the removal percentages would vary between $8 \%$ and $9 \%$ for sections $\mathrm{A}$ and $\mathrm{B}$ and $17 \%$ for section $\mathrm{C}$.

\section{Discussion}

\section{Water balance}

Since no runoff has been observed in the discharge field, the significant amounts of irrigation and precipitation compared with the evapotranspiration suggest that the soil water retention capacity would have been exceeded, and the excess of water will be percolated to deeper layers. Currently Knowle's irrigation rate is $13600 \mathrm{~mm} / \mathrm{a}$; which situates it in the high rate range for LTS (Crites, Middlebrooks, \& Sherwood (2006). This percolation to deeper layers may be also be enhanced by preferential flow produced in soil macro-pores. 


\section{Phosphorus inputs over the study period}

The $\mathrm{P}$ inputs estimations of the discharge field are comparable to other published values, however, they have to be carefully approached due to several limitations in the calculations of the $\mathrm{P}$ added to the field. The main constraint in the analysis is the lack of a complete dataset of inlet- outlet P concentrations of the STW over the study period. To calculate the P load into the field, the preliminary hypothesis of the irrigation periods from the water company operating the plant of a section of the field never been irrigated was discarded, and instead, the irrigation periods were stabilised in relation to the evidence of the presence of the irrigation pipe on historical maps (from 1881) (Landmark Information Group 1932). However, the maps referred to broad periods of time with the consequent inaccuracy.

Although other studies, such as White and Hammond (2009), quantified very similar values of P contributions from human excreta, household waste, and detergents ( $2.05 \mathrm{~g} /$ capita/day) in England and Wales, its evolution over time in the hospital was assumed to resemble the domestic national trend, which was driven by the introduction of washing machines. It is assumed that domestic wastewater composition is comparable to that of hospitals because it was not a surgical hospital and patients were living there. The influence of changes in diet over time could also be relevant to the P content in the wastewater, but this was not accounted for in this study since it has not been quantified yet. In addition, there is uncertainty regarding the hospital population between known data from hospital registrations.

Despite the differences in the P loads, no significant differences were found in the mean TP concentration $\left(\mathrm{C}_{\mathrm{p}}\right)$ of the three sections. $\mathrm{C}_{\mathrm{p}}$ values were higher than the regional average (943 $\mathrm{mgP} / \mathrm{kg})$ and adjacent site references $(938 \mathrm{mgP} / \mathrm{kg})$ and close to the soil P sorption maximum $\left(\mathrm{S}_{\max }\right)$ of $1240 \mathrm{mg} \mathrm{P} / \mathrm{kg}$ reported by Tyrrell (2016) for the adjacent site. This suggests that the soil is saturated with P irrespective of the duration of the irrigation (Figure 3). However, it is unknown when this Smax removal capacity was reached. All but one of the TP concentrations of the 30 samples were between the maximum (3 $996 \mathrm{mg} \mathrm{P} / \mathrm{kg}$ ) and minimum (296 mg P/kg) values for TP background levels from top soil analyses of $50 \mathrm{~km}$ radius for loam clay texture soils and permanent grassland land use (National Soil Resources Institute 2014). The sampling point that is out of the upper range is situated very close to a former discharge point, which means that it is more likely that has received more $\mathrm{P}$ through irrigation than other points of the field. 


\section{Phosphorus removal}

The removal was low compared with other similar mass balance calculation studies of $\mathrm{P}$ removal in soils. Those studies reported $\mathrm{P}$ removal between $58 \%$ and $99 \%$, for treatments aged between 10 and 27 years old (Dzakpasu et al. 2015; Jenssen et al. 2014; Zhang and Dahab 2006). Only Eveborn et al. (2012) identified low removal ( 12\%) such as the ones obtained for Knowle's system. The main difference between Eveborn's experiments and the other studies is that removal was calculated through P concentrations in the soil, as was the case in this study, rather than inlet/outlet water quality samples of the system. The main drawback of using $\mathrm{P}$ concentrations for $\mathrm{P}$ removal calculations is the strong influence in the results of the $\mathrm{P}$ concentration in the reference sample. However, it simplifies the process of selecting the outlet sampling points which are usually harder to identify or to access than in large and engineered soil treatment systems studies. Traditional inlet/outlet field measurements entail methodological limitations such as: the difficulty of finding representative inlet/outlet flow and sampling locations, insufficient monitoring time, or lack of representation of groundwater interactions (Eveborn et al. 2012). Reddy et al. (1999) pointed out the difficulty to identify outputs and inputs of $\mathrm{P}$ and water as one of the main challenges in $\mathrm{P}$ assimilation studies in natural wastewater treatments, along with the lack of monitoring and laboratory methodologies. Such discrepancies make it difficult to compare studies and removal performances of different treatments. P removal at the sections indicates that not all the phosphorus discharged has been accumulated, and that if the soil could accumulate all the P discharged, the binding capacities would have been higher than engineered filter materials such as Filtralite ${ }^{\odot}$ or steel slag, which have P sorption capacities between 1350 and $4300 \mathrm{mg} \mathrm{P} / \mathrm{kg}$ (Cucarella and Renman 2009; Herrmann et al. 2012) 


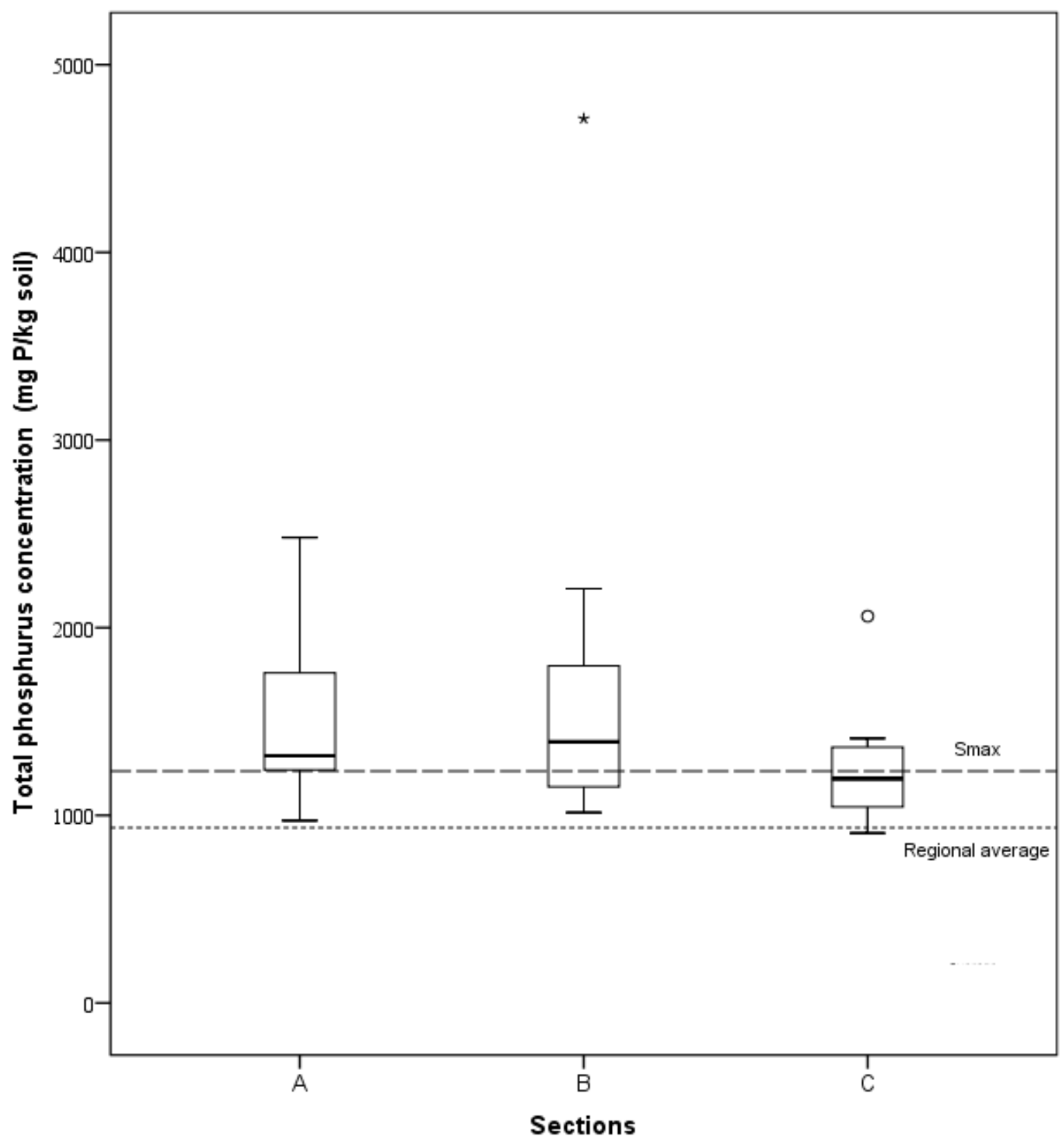

Figure 3 Measured total phosphorus in soil in each section. Box plot show median values (solid horizontal line), boundaries of the box indicate the interquartile (IQ) and whiskers show sample minimum and maximum. Outliers (o) are cases with values between 1.5 and 3 times the IQ range and extremes (*) are cases with values more than 3 times the IQ range. Regional average value show the National Soil Inventory mean value of 560 samples for total phosphorus analysis within a $50 \mathrm{~km}$ radius from the sampling site for clay loam type soil and permanent grassland land use $(\operatorname{mean}=943.0, \min =\mathbf{2 6 9 . 0}, \max =$ 3996.0 st.dev= 403.02). Smax, $P$ maximum sorption capacity from Tyrrell (2016) clay loam soil texture and grassland land use from Knowle STW site. 


\section{Phosphorus pathways (where is the P?)}

The difference between the TP soil concentration and the estimated P load raises questions concerning the fate of the discharged P. Soil P retention mechanisms are physical, chemical, biological processes and/or plant uptake (Crites et al. 2000). Physical retention can retain P by deposition and infiltration, where vegetation and dense root systems help to decrease water velocity and increase contact time of $\mathrm{P}$ with the soil surface, this mechanism has greater influence in particulate $P$ than dissolved P (Roberts et al. 2012). Analysis of wastewater at Knowle (Albion Water, personal communication 2015) reported that $90 \%$ of TP is dissolved phosphate, which means that this physical retention mechanism will be less influential than others. Plant and microbial uptake can also remove P from the soil. Crites et al. (2006) proposed typical annual phosphorus nutrient uptake rates for forage crops in LTS to be in the range of $20-84 \mathrm{~kg} / \mathrm{ha} / \mathrm{a}$. Since the history of the site land management is uncertain, no plant uptake has been considered in this study, however, if $\mathrm{P}$ was assimilated at this rate and vegetation had been harvested and removed then plant uptake would account for $\approx 5 \%$ of the $\mathrm{P}$ applied to the soil $\left(\mathrm{P}_{\mathrm{d}}\right)$. Phosphorus can be also stored as soil microbial biomass. Brookes et al. (1984) quantified the microbial $\mathrm{P}$ mean annual flux of 8 grassland to be $23 \mathrm{~kg} \mathrm{P} / \mathrm{ha} / \mathrm{yr}$, what will account for $\approx 4 \%$ of the $\mathrm{P}$ applied to the soil $\left(\mathrm{P}_{\mathrm{d}}\right)$.

It is also plausible that part of the discharged $\mathrm{P}$ is retained in the soil, but it was not identified during sampling due to the high variability of $\mathrm{P}$ in the field because of the irrigation methodology. This could be linked with the high variability of TP concentration found in sections $\mathrm{A}$ and $\mathrm{B}$, represented by the higher interquartile in sections $\mathrm{A}$ and $\mathrm{B}$ compared to $\mathrm{C}$, and by the outlier point with high TP content situated close the discharge pipe (Figure 3 ). The high variability could be caused by non-uniform distribution of the wastewater over the field generated by the natural topography of the field, enhanced by the channelling caused by running water flow for long periods and the arbitrary opening of the discharge gates for irrigation. Moura et al. (2011) also observed high spatial variability in water extractable phosphorus concentrations after 25 years of reclaimed water application in rapid infiltration basins. The minimum values in each section are close to the reference concentrations, which could also suggest poor uniformity of distribution in the field.

However, if $\mathrm{P}$ has flowed downwards to deeper soil layers, it could be either adsorbed at deeper levels (if the soil solution in deeper layers is less concentrated) or leached to the groundwater. The subsurface water connections between the field, the River Meon and the groundwater are 
unknown. However, Tyrrell (2016) measured the $\mathrm{PO}_{4}^{-3}$ concentration in the River Meon, upstream and downstream of the discharge field monthly from June 2012 to July 2014. This revealed no statistical significance $(\mathrm{t}=1.459 ; \mathrm{p}=0.156)$ in paired samples $\mathrm{t}$-test between both sampling sites. Therefore, the discharge field has no detectable effect on the $\mathrm{PO}_{4}^{-3}$ concentration in the river. It is plausible that $\mathrm{P}$ from the discharge field reaches surface and groundwater but in insufficient loads to affect concentrations appreciably. However, this hypothesis was not possible to test in this study by obtaining data from a groundwater assessment. This unfeasibility is due to limitations in the accessibility by the landowner. If access for groundwater studies can be granted in the future, a further study would be necessary to be able to provide additional data of groundwater quality to support this hypothesis and to assess whether the $\mathrm{P}$ has been storage or release.

\section{Practical implications of the study}

There is a lack of field case studies of P removal capability in existing LTS, in longevity methodology predictions and discussion of future applications. This case study has demonstrated that, although the sorption capacity of the system seems to be saturated, it has retained significant amounts of $\mathrm{P}$, and that the $\mathrm{P}$ that has not been retained has appears to have had no significant impact on the receiving waterbodies. The $\mathrm{P}$ retention capacity is finite and this has to be taken into consideration for the future role of these systems. Therefore, there is a need to build knowledge regarding: management practices for $\mathrm{P}$ removal optimization, such as, which P loads and P loading modes would contribute towards a higher removal rates or which type of plant and approach to vegetation management could improve longevity. These results can help designers and operators to evaluate LTS performance and their potential implementation. However, such evaluations need to consider P removal in the context of the other functions and services provided by LTS.

\section{Conclusions}

The duration of wastewater irrigation activity at Knowle ( $\sim 85$ years) offered the possibility to study a unique LTS by comparing the P concentration in the soil of areas that have been irrigated with wastewater for different periods. The different sections of the discharge field did not show significant difference in the soil TP concentration despite being irrigated for different 
periods with secondary treated wastewater and the $\mathrm{P}$ concentration levels indicated that the soil has reached $\mathrm{P}$ saturation capacity. The TP retention (4\%) was low compared with similar previous studies, which was mainly attributed to the exhaustion of the sorption capacity possibly many years or even decades ago. However, no evidence of nutrient pollution has been detected in the nearby water bodies (River Meon and East Hants Chalk aquifer), suggesting that the LTS is not affecting phosphate levels in the river or producing relevant nutrient contamination.

Assessment of P removal performance in small long-term LTS can be challenging due to the lack of historical datasets and outlet monitoring, thus methodologies based on $\mathrm{P}$ accumulation in the soil could help to overcome this drawback, however representative reference samples are needed since the results are strongly influenced by them.

These findings suggest that LTS can play a role in low energy phosphorus removal at small works, in addition to the other contributions they make to tertiary treatment and habitat provision. Gaps remain, however, in our knowledge of how to optimise their performance through design and operational measures, and in how to forecast their longevity and how to manage the finite adsorption potential of the soil.

\section{Acknowledgements}

This research was funded and supported by Albion Water Ltd. and a Cranfield University Industrial Partnership. The authors would like to thank Neil McGarrick (Albion Water Ltd.) for his onsite support and advice. 


\section{References}

Allen, R.G., Pereira, L.S., Raes, D., et al., 1998. Crop evapotranspiration - Guidelines for computing crop water requirements - FAO Irrigation and drainage paper 56.

Anglian Water Ltd., 2008. Fact file 5 "Using water at home." Available at: https://www.anglianwater.co.uk/_assets/media/Fact_File_5__Using_water_at_home.pdf [Accessed December 3, 2015].

Austin, D. and Nivala, J., 2009. Energy requirements for nitrification and biological nitrogen removal in engineered wetlands. Ecological Engineering, 35(2), pp.184-192.

Batista, M. del M., Hess, T., Sakrabani, R., et al., 2017. Long-term phosphorus removal in Land Treatment Systems: evaluation, experiences and opportunities. Critical Reviews in Environmental Science and Technology, 47(5), pp.314-334.

Brookes, P.C., Powlscin, D.S. and Jenkinsdn, D.S., 1984. Rothamsted IN THE SOIL MICROBIAL BIOMASS NaHCO ,. In this work we investigated the re-. Soil Biology and Biochemistry, 16(2), pp.169-175.

BSI Standards Limited., 1998. BS 7755-3.13:1998, ISO 11047:1998 Soil quality. Chemical methods. Determination of cadmium, chromium, cobalt, copper, lead, manganese, nickel and zinc in aqua regia extracts of soil. Flame and electrothermal atomic absorption spectrometric methods,

BSI Standards Limited., 2006. BS ISO 11464:2006 Soil quality. Pretreatment of samples for physio-chemical analysis,

Burt, S.M., 2003. "Fit Objects for an Asylum” The Hampshire County Lunatic Asylum and its Patients, 1852-1899. P.h.D Thesis. University of Southampton.

Centre for Ecology \& Hydrology, 2007. Model estimates of topsoil properties [Countryside Survey] data owned by NERC - Centre for Ecology \& Hydrology, Available at: http://mapapps2.bgs.ac.uk/ukso/home.html?layer=CEHTSBulkDensity September 9, 2016].

Charlesworth, S.M., Bennett, J. and Waite, A., 2016. An evaluation of the use of individual grass species in retaining polluted soil and dust particulates in vegetated sustainable drainage devices. Environmental Geochemistry and Health, 38(4), pp.973-985.

Crites, R.W., Middlebrooks, J.E. and Sherwood, C.R., 2006. Natural wastewater treatment systems, Boca Raton: CRC Press.

Crites, R.W., Reed, S.C. and Bastian, R.K., 2000. Land treatment systems for municipal and industrial wastes, New York: McGraw-Hill.

Cucarella, V. and Renman, G., 2009. Phosphorus sorption capacity of filter materials used for on-site wastewater treatment determined in batch experiments - a comparative study. Journal of Environmental Quality, 38(2), pp.381-92.

Dzakpasu, M., Scholz, M., McCarthy, V., et al., 2015. Assessment of long-term phosphorus retention in an integrated constructed wetland treating domestic wastewater. 
Environmental Science and Pollution Research, 22(1), pp.305-313.

Environment Agency, 2016. Water for life and livelihoods. Part 1: South East river basin district. River basin management plan., Bristol. Available at: https://www.gov.uk/government/uploads/system/uploads/attachment_data/file/500463/A nglian_RBD_Part_1_river_basin_management_plan.pdf [Accessed May 19, 2017].

Eveborn, D., Gustafsson, J.P., Elmefors, E., et al., 2014. Phosphorus in soil treatment systems: accumulation and mobility. Water research, 64, pp.42-52.

Eveborn, D., Kong, D. and Gustafsson, J.P., 2012. Wastewater treatment by soil infiltration: Long-term phosphorus removal. Journal of Contaminant Hydrology, 140-141, pp.24-33.

Falkiner, R.A. and Polglase, P.J., 1999. Fate of applied phosphorus in an effluent-irrigated Pinus radiata plantation. Australian Journal of Soil Research, 37(6), pp.1095-1106.

Force, T., Mallarino, M. a P., Beegle, D.B., et al., 2006. Soil Sampling Methods for Phosphorus - Spatial Concerns A SERA-17 Position Paper. Methods, 1, pp.1-16.

Foundation for Water Research, 2006. Eutrophication of freshwaters, Available at: www.fwr.org/eutrophi.pdf [Accessed September 30, 2016].

Gilmour, D., Blackwood, D., Comber, S., et al., 2008. Identifying human waste contribution of phosphorus loads to domestic wastewater. In Preceedings at the 11th International Conference on Urban Drainage, Held in Edinburgh, Scoltand, UK,. pp. 1-10.

Gray, N.F., 1989. Biology of wastewater treatment, New York: Oxford University Press.

Herrmann, I., Jourak, A., Lundström, T.S., et al., 2012. Phosphorus binding to Filtra P in batch tests. Environmental technology, 33(7-9), pp.1013-9.

HMSO, 1973. Water Act, Chapter 37. London: HMSO, 120,

Jenssen, P.D., Krogstad, T. and Halvorsen, K., 2014. Community wastewater infiltration at 69 o northern latitude - 25 years of experience. In Soil Science Society of America Onsite Wastewater Conference, Albuquerque NM, 7-8 April 2014.

Keller, V.D.J., Tanguy, M., Prosdocimi, I., et al., 2015. CEH-GEAR: $1 \mathrm{Km}$ resolution daily and monthly areal rainfall estimates for the UK for hydrological and other applications. Earth System Science Data, 7(1), pp.143-155.

Land and Water Division of FAO, 2012. ETo Calculator. Version 3.1 Land and Water Digital Media Series No 36.

Landmark Information Group, 1932. Ordnance Survey County Series 1:2500, 1:2500, 1st Revision 1893-1915 and 3rd Revision 1924-1949 [TIFF geospatial data], County/Tile: Hampshire and Isle of Wight, Published: 1932-1940. Using: EDINA Historic Digimap Service, $<$ http://digimap.edina.ac.uk/>.

Mettofice, 2016. UK climate - Historic station data. Available at: https://www.metoffice.gov.uk/public/weather/climate-historic/\#?tab=climateHistoric [Accessed February 24, 2016].

Moura, D.R., Silveira, M.L., O’Connor, G.A., et al., 2011. Long-term reclaimed water 
application effects on phosphorus leaching potential in rapid infiltration basins. Journal of Environmental Monitoring, 13(9), pp.2457-62.

National Soil Resources Institute, 2014. Full Soils Site Report for location 455716E, 108933N, $2 \mathrm{~km}$ x 2km, National Soil Resources Institute, Cranfield University. , pp.1-27.

O’Keeffe, J., Akunna, J., Olszewska, J., et al., 2015. Practical measures for reducing phosphorus and faecal microbial loads from onsite wastewater treatments systems discharged to the environement. A review. Scotland's Center of Expertise for Waters $(C R E W)$.

Office of National Statistics, 2013. Census: Population and household estimates for the United Kingdom, March 2011, Available at: https://www.ons.gov.uk/peoplepopulationandcommunity/populationandmigration/popul ationestimates/bulletins/populationandhouseholdestimatesfortheunitedkingdom/201103-21 [Accessed January 1, 2017].

Reddy, K.R., Kadlec, R.H., Flaig, E., et al., 1999. Phosphorus Retention in Streams and Wetlands: A Review. Critical Reviews in Environmental Science and Technology, 29(1), pp.83-146.

Roberts, W.M., Stutter, M.I. and Haygarth, P.M., 2012. Phosphorus Retention and Remobilization in Vegetated Buffer Strips: A Review. Journal of Environment Quality, 41(2), p.389.

Smith, V.H., 2003. Eutrophication of freshwater and coastal marine ecosystems: a global problem. Environmental Science and Pollution Research, 10(2), pp.126-139.

Sweaney, G., 2011. The performance of sustainable wastewater treatment works solutions. Report Ref. NO. 11/WW/04/16, UK Water Industry Research.

Taebi, A. and Droste, R.L., 2008. Performance of an overland flow system for advanced treatment of wastewater plant effluent. Journal of Environmental Management, 88(4), pp.688-696.

Tyrrell, S.R., 2016. Microtopographic enhancement of land-based wastewater treatment. $\mathrm{PhD}$ Thesis. Cranfield University.

Tzanakakis, V.E., Paranychianakis, N. V. and Angelakis, A.N., 2007. Soil as a wastewater treatment system: Historical development. Water Science and Technology: Water Supply, 7(1), pp.67-75.

White, P.A. and Hammond, J.P., 2009. The sources of phosphorus in the waters of Great Britain. Journal of environmental quality, 38, pp.13-26.

Zhang, T.C. and Dahab, M.F., 2006. Phosphorous sorption capacity and distributions in soil after long-term wastewater land treatment in Muskegon, Michigan, Kansas City: EPA. 